The Journal of Animal \& Plant Sciences, 30(4): 2020, Page: 780-785

ISSN: 1018-7081

\title{
CORRELATION OF LINEAR TYPE TRAITS WITH MILK YIELD IN NILI RAVI BUFFALOES OF PAKISTAN
}

\author{
R. H. Mirza ${ }^{1}$, A. Waheed ${ }^{1}$, M. Akhtar ${ }^{2}$, M. A. Khan ${ }^{3}$, S. M. R. Dilshad ${ }^{4}$ and A. Faraz ${ }^{1}$ \\ ${ }^{1}$ Department of Livestock and Poultry Production, Faculty of Veterinary Sciences, Bahauddin Zakariya University, \\ Multan, Pakistan; ${ }^{2}$ Buffalo Research Institite, Pattoki, Distt. Kasur, Pakistan; ${ }^{3}$ Department of Breeding and Genetics, \\ Faculty of Animal Production and Technology, Cholistan University of Veterinary and Animal Sciences, Bahawalpur- \\ 63100, Pakistan; ${ }^{4}$ Gomal College of Veterinary Sciences, Gomal University, Dera Ismail Khan, Pakistan \\ Corresponding Author's Email: riazmirza71@yahoo.com
}

\begin{abstract}
Nili Ravi buffaloes are considered black gold being highest milk producers in the world. The study was performed for genetic evaluation of linear type traits and explore their relationships with milk production traits of Nili Ravi buffaloes. Data on Nili Ravi Buffaloes $(\mathrm{n}=437)$ present at 5 experimental livestocks farms in Punjab, Pakistan were recorded for linear type traits follwoing ICAR gudelines and adopting a linear scale of 1-9 during 2010-2012 encompassing 1180 records for each trait. A mixed effect model was applied where herd, year, parity, season were fitted as fixed effects and age as covariable. All analyses were performed by using Proc GLM of the SAS software. Variance components were estimated by ASREML software and genetic parameters were computed by post-processing. Least square means for linear scores of stature, chest width, body depth, angularity, rump angle and rump width were $5.07 \pm 1.35,5.23 \pm 2.35$, $5.41 \pm 1.49,5.76 \pm 0.98,6.73 \pm 1.53,4.91 \pm 1.85$, respectively. Corresponding genetic correlations $\left(\mathrm{r}_{\mathrm{G}}{ }_{\mathrm{G}}\right)$ of linear scores of the traits with test day milk yield were $0.57 \pm 0.05,0.09 \pm 0.02,0.31 \pm 0.04,0.06 \pm 0.02,0.15 \pm 0.03$ and $0.30 \pm 0.05$, respectively while with 305 days milk yield were $0.14 \pm 0.00,0.04 \pm 0.00,0.21 \pm 0.00,0.02 \pm 0.00,0.11 \pm 0.00$ and $0.19 \pm 0.00$, respectively. It was found that some of traits (stature, body depth and rump width) had considerable amount of $\mathrm{r}_{\mathrm{G}}{ }_{\mathrm{G}}$ with milk yield. It is therefore suggested that any selection model for Nili Ravi buffalo must contain these useful linear type traits.
\end{abstract}

Key words: Linear type traits, genetic parameters, Nili Ravi buffalo, selection

https://doi.org/10.36899/JAPS.2020.4.0091

Published online April 25, 2020

\section{INTRODUCTION}

Nili Ravi is the most popular and major buffalo breed in Pakistan. This breed has great potential for high milk yield and a vast variation exists in its production performance. This variation provides a base for improvement however, actual potential of this breed has not yet been exploited. Physical appearance and fitness of the animal is the only tool with a farmer to select or reject an animal at field level. This selection process of animals on the basis of body appearance and conformation has long been used in various species and breeds with in species. Body type and conformation is still considered very important and is studied on scientific lines in different dairy cattle breeds.

The term linear type scoring is used nowadays to describe physical appearance of the dairy cows and they are evaluated for functional or linear traits. Most often the performance traits are correlated with each other and with other body features including body size, shape and conformation traits. Type traits are considered very important because they have been reported to be correlated with performance traits of animals. Positive correlation between milk production and stature has been documented by various researchers (Haas et al., 2007; Zink et al., 2014; Bohlouli et al., 2015). Correlations of different magnitude and nature have been reported between milk yield (MY) and linear traits like; milk yield has negative correlation with chest width (Khan and Khan, 2016) positive correlation with body depth (Tapki and Guzey, 2013), positive correlation with angularity (Bilal et al., 2016), highly positive correlation with rump angle (Jadoa, 2010) and positive $\mathrm{r}^{2} \mathrm{p}$ with rump width (Alimzhanova et al., 2018). The estimated genetic correlations for type traits can be used for indirect selection for milk production. Keeping in view the importance of body type and conformation traits established in various dairy cattle breeds in advanced production set ups, the present study on conformation recording was planned because there was lack of studies on this aspect of Nili Ravi buffaloes. Hence it was aimed to determine asscoaition of linear type traits with milk yield to serve as standard for inclusion in selection program for Nili Ravi buffaloes. 


\section{MATERIALS AND METHODS}

Data on linear type traits and milk yield of Nili Ravi buffaloes maintained at 5 government research stations under the umbrella of Buffalo Research Institute, at Pattoki in Punjab, Pakistan were recorded from 20102012. Buffaloes were maintained in open sheds with routinely 4-6 hours grazing on available fodders on daily basis usually in the morning just after completion of milking. The duration of grazing was dependant on season and quality of vegetation. Concentrates were offered to all in-milk buffaloes @ 1 kg for every 3 liters of milk production and rock salt was suplied in feeding mangers as a free lick. The buffaloes were hand-milked twice a day with an approximate interval of 12 hours. Calves were allowed to suckle their dams to facilitate proper milk let down. In case of death of the calf, concentrate was offered along with massaging of udder to stimulate milk let down.

Data collection: Conformation recording was carried out for 3 years during 2010 to 2012. Information including tag number of the buffalo, sire and dam number and pedigree records of sire and dam, date of birth, date of calving, lactation number, age and weight at first calving, live weight, calf sex, calf number, calf birth weight, fertility status on scoring date and other relevant data were collected.

Buffaloes were scored for linear type traits between 7.00 AM to 3.00 PM daily. Milk yield (kg) was recorded using digital weighing scale. Daily milk yield one day before the scoring, on the scoring day and one day after the scoring was recorded and averaged as score day milk yield (SC-MY). The International Committee for Animal Recording (ICAR, 2007) guidelines for dairy cattle were followed for conformation recording. Milking buffaloes $(\mathrm{n}=437)$ were scored 15 to 90 days, $90-180$ and 180-270 days after calving.

The approved traits included stature, chest width, body depth, angularity, rump angle and rump width. Scale of converting body measurements into linear score are given in Table 1 .

Table 1. Development of linear score system for Nili Ravi buffaloes.

\begin{tabular}{lcccc}
\hline Trait & & \multicolumn{2}{c}{ Score } & \\
\hline Stature & Measurement $(\mathrm{cm})$ & Up to $130 \mathrm{~cm}$ & $131-140 \mathrm{~cm}$ & $141 \mathrm{~cm}$ and above \\
& Linear Score & $1-3$ & $4-6$ & $7-9$ \\
Chest width & & $($ short) & (intermediate) & (tall) \\
& Measurement $(\mathrm{cm})$ & Up $21 \mathrm{~cm}$ & $22-24 \mathrm{~cm}$ & $25 \mathrm{~cm}$ and above \\
& Linear Score & $1-3$ & $2-6$ & $7-9$ \\
Body depth & Measurement $(\mathrm{cm})$ & (Narrow) & (Intermediate) & (Wide) \\
& Linear Score & Upto $70 \mathrm{~cm}$ & $71-81 \mathrm{~cm}$ & 82 cm and above \\
& & $1-3$ & $2-6$ & $7-9$ \\
Angularity & Measurement & (Shallow) & (Intermediate) & (Deep) \\
& Linear Score & & Visual Score & $7-9$ \\
Rump angle & & $1-3$ & $2-6$ & Very angular \\
& Measurement (degree) & (Lacks angularity) & (Intermediate) & 18 and above \\
& Linear Score & Not found & Up to 17 & $7-9$ \\
Rump width & Measurement $(\mathrm{cm})$ & (High Pins) & (Intermediate slope) & (Extreme Slope) \\
& Linear Score & Upto $14 \mathrm{~cm}$ & 14.5 to $17 \mathrm{~cm}$ & $17.5 \mathrm{~cm}$ and above \\
& & $1-3$ & $2-6$ & $7-9$ \\
& & (Narrow) & (Intermediate) & (Wide) \\
\hline
\end{tabular}

\begin{abstract}
Data were analyzed by applying Individual Animal Model following Restricted Maximum Likelihood (REML) Procedure as outlined by Patterson and Thompson (1971). Different factors such as age of the buffalo at scoring, stage of lactation, parity, herd and season were included in the model. Months of a year were divided in to 5 seasons as defined by Mirza et al. (2013). Fixed effects were herd ( 1 to $\left.5^{\text {th }}\right)$, recording season ( 1 to 5$)$, lactation number (1-4 $\left.4^{\text {th }}\right)$, lactation stage (4 levels including early, intermediate, late and dry stage) and age in months of the buffalo on recording day. Initial
\end{abstract}

analysis was carried out by using SAS mixed model (SAS, 2011). Only significant effects were used in final model for computing variance components (VC) and heritabilities of various linear type traits were estimated accordingly.

The ASREML (Gilmour, 2009) computer software was used for estimating VCs and heritability. Following animal model was assumed:

$\mathrm{Y}_{\mathrm{ijk}}=\mu+\mathrm{F}_{\mathrm{i}}+\mathrm{A}_{\mathrm{j}}+\mathrm{e}_{\mathrm{ijk}}$

Where $Y_{\mathrm{ijk}}=$ measurement of a particular trait, $\mu=$ population mean, $F_{i}=$ fixed effects observed to be 
significant from the initial analyses, $A_{j}=$ random additive genetic effect of $j^{\text {th }}$ animal with mean zero and variance $\sigma^{2}{ }_{\mathrm{A}}$ and $e_{\mathrm{ijk}}=$ random error with mean zero and variance $\sigma^{2}$ A. Bivariate analysis was performed for computing genetic and phenotypic correlations using ASREML (Gilmour, 2009).

\section{RESULTS AND DISCUSSION}

Pedigree records of buffaloes up to 5 generations back revealed that these buffalkoes were the progeny of 88 sires and 303 dams. Least Squares Means for linear type traits are presented in Table 2. Genetic and phenotypic correlations with 305 days milk yield and score day yield are presented in Table 3 which in general were very low. Genetic correlations though positive yet very low but phenotypic correlations of chest width and angularity were negative too. On the other hand, score day milk yield possessed low and negative phenotypic correlations with linear traits while genetic correlations were positive and approaching to 0.57 with stature that appeared to be best indicator of test day milk yield.

Correlations are useful tools for predicting milk yield in buffaloes and most are part of selection systems for dairy animals. Linear type traits showed variable degrees of relationships with milk production.

Stature: Phenotypic correlations $\left(\mathrm{o}^{2} \mathrm{P}\right)$ of stature with SCMY and MY-305 were $0.09 \pm 0.03$ and $0.02 \pm 0.03$, respectively. Almost similar estimates for $\sigma^{2} \mathrm{P}$ of stature with milk yield were reported as 0.10 in Ayrshire and Jersey cows (Norman, 1988), 0.08 in Holstein grade cows (Short and Lawlor, 1992), 0.05 in Holstein cows (Bilal et al., 2016) and $0.10 \pm 0.02$ in Holstein cows (Bohlouli et al., 2015). Slightly higher estimate was reported as 0.14 (Tapki and Guzey, 2013). Higher estimates have been reported by many workers in Sahiwal cows as $0.44 \pm 0.08$ (Dahiya and Rathi, 1997), in Guernsey cows as 0.24 (Cruickshank et al., 2002) and as 0.29, 0.16 and 0.19 in Holstein, Brown Swiss and Red and White cows, respectively (Haas et al., 2007). Yanar (1999) has reported a phenotypic correlation of 0.0003 with MY305. Most of the workers have reported higher phenotypic correlation of stature with milk yield than the findings of current study.

Stature had genetic correlations with SC-MY and MY-305 as $0.57 \pm 0.05$ and $0.14 \pm 0.00$, respectively. The finding of Haas et al. (2007) for genetic correlation of statute with milk yield as $0.47,0.47$ and 0.61 in Holstein, Brown Swiss and Red and White cows, respectively are matching with present results. Some other workers have reported negative genetic correlation of stature with milk yield $(-0.24)$ contradicting present findings (Devan et al., 1991), -0.15 (Short and Lawlor, 1992), -0.11 (Parke et al., 1999) in Holstein cows, -0.09 (Campos et al., 2015). Slightly higher value as $0.19 \pm$

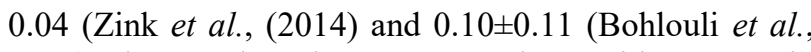
2015) have also been reported. Positive genetic correlation of stature with milk yield gives insight that taller and heavier buffaloes produced more milk and selection for taller buffaloes may result in improved milk yield but the efficiency of milk yield must be studied before making indirect selection for milk yield through stature. Xiang et al. (2017) identified CTU1 as one of the strongest pleotropic loci with a wide range of effects on non production dairy traits including increasing stature and chest width although the gene function of CTU1 is unknown. Its wide spred effect on various traits suggests that it is an important marker for a balance of dairy cattle. Genomic studies to identify genes affecting stature and milk yield in Nili Ravi buffaloes will be helpful for early selection in this breed.

Chest width: A negative phenotypic correlation of chest width with score day milk yield $(-0.21 \pm 0.03)$ and 305 days milk yield $(-0.02 \pm 0.04)$ has been estimated. Tapki and Guzey (2013) has reported similar correlations (0.04). Khan and Khan (2016) has also shown similar findings $(-0.17 \pm 0.0)$ for score day milk yield. Yanar (1999) showed negative phenotypic correlation (-0.09) between chest width and 305 days milk yield.

A genetic correlation of positive nature $(0.10)$ has been present between chest width and milk yield agreeing other researchers (Zink et al., 2014; Khan and Khan, 2016). Almost similar value has been reported as $0.12 \pm 0.09$ (Bohlouli et al., 2015). Negative phenotypic correlation of chest width with score day milk yield suggests that buffaloes with wider chest and front region of body show blocky appearance and are relatively less efficient in milk production. However, further studies are needed with larger data set to verify the results. Xiaoping et al. (2013) identified 59 SNPs associated with 26 conformation traits in Chinese Holstein cattle population and found that GAS1 was the most promising candidate gene for chest width. In the current Genomic era, identification of genes controlling type traits and genomic association of conformation traits withn each other and with production traits in Nili Ravi buffaloes will greatly be helpful to select superior animals on the basis of genomic EBVs.

Body depth: Negative phenotypic correlation of body depth with score day milk yield (-0.05 \pm 0.04$)$ but positive phenotypic correlation with 305 days milk yield $(0.18 \pm 0.04)$ was observed in current study. A positive phenotypic correlation (0.17) between body depth and milk yield (Haas et al. 2007) in Red and White cows showed similarity with current study. However, the same report indicated a very high value $(0.58)$ for Holstein cows. Many workers have reported this correlation as positive ranging from 0.10 to 0.30 as $0.10 \pm 0.02$ (Bohlouli et al., 2015), 0.11 (Tapki and Guzey, 2013) and 0.11 (Bilal et al., 2016). 
Table 2. Least squares mean for linear type traits in Nili Ravi buffaloes

\begin{tabular}{cccccc}
\hline Sr.No. & Trait & N & Mean \pm Std Dev & $\begin{array}{c}\text { Coefficient of } \\
\text { Variation(\%) }\end{array}$ & Range \\
\hline 1 & Stature & 1180 & $5.07 \pm 1.348$ & 26.612 & $1-9$ \\
2 & Chest width & 1180 & $5.23 \pm 2.349$ & 44.914 & $1-9$ \\
3 & Body depth & 1091 & $5.41 \pm 1.487$ & 27.475 & $1-9$ \\
4 & Angularity & 1180 & $5.76 \pm 0.978$ & 16.985 & $3-8$ \\
5 & Rump angle & 1177 & $6.73 \pm 1.532$ & 22.779 & $4-9$ \\
6 & Rump width & 1169 & $4.91 \pm 1.85$ & 37.656 & $1-9$ \\
\hline
\end{tabular}

Table 3. Genetic and phenotypic correlations of linear type traits with milk yield in Nili Ravi buffaloes

\begin{tabular}{lllll}
\hline & \multicolumn{2}{c}{ 305 days milk yield } & \multicolumn{2}{c}{ Score day milk yield } \\
\hline Trait & $\begin{array}{l}\text { Phenotypic } \\
\text { correlations }\end{array}$ & $\begin{array}{l}\text { Genetic } \\
\text { correlations }\end{array}$ & $\begin{array}{l}\text { Phenotypic } \\
\text { correlations }\end{array}$ & $\begin{array}{c}\text { Genetic } \\
\text { correlations }\end{array}$ \\
\hline Stature & $0.021 \pm 0.027$ & $0.140 \pm 0.0001$ & $0.094 \pm 0.031$ & $0.573 \pm 0.054$ \\
Chest width & $-0.025 \pm 0.042$ & $0.040 \pm 0.0001$ & $-0.215 \pm 0.032$ & $0.091 \pm 0.021$ \\
Body depth & $0.178 \pm 0.037$ & $0.210 \pm 0.0001$ & $-0.053 \pm 0.037$ & $0.311 \pm 0.038$ \\
Angularity & $-0.050 \pm 0.04$ & $0.020 \pm 0.0000$ & $-0.174 \pm 0.034$ & $0.057 \pm 0.015$ \\
Rump angle & $0.147 \pm 0.040$ & $0.110 \pm 0.0001$ & $-0.118 \pm 0.034$ & $0.150 \pm 0.027$ \\
Rump width & $0.126 \pm 0.045$ & $0.195 \pm 0.0002$ & $-0.165 \pm 0.048$ & $0.300 \pm 0.049$ \\
\hline
\end{tabular}

Genetic correlations of body depth with SC-MY and MY-305 were $0.31 \pm 0.04$ and $0.21 \pm 0.00$ and are in line with the findings of other workers (Short and Lawlor (1992; Cruickshank et al., 2002; Tapki and Guzey, 2013) as 0.28. However, Bohlouli et al. (2015) showed different value $(0.14 \pm 0.17)$. Highest genetic correlation between these traits was 0.48 in Holstein cows (Haas et al., (2007). Therefore, indirect selection might be considered for the positive relationship of body depth with milk yield.

Angularity: Angularity appeared to have negative correlation with SC-MY (-0.17 \pm 0.03$)$ and MY-305 ($0.05 \pm 0.04)$ in current study. Low phenotypic correlations of angularity with milk yield as 0.03 (Yanar, 1999) and $0.05 \pm 0.06$ (Khan and khan, 2016) have been reported contradicting with our study. On the other hand, we found very low positive genetic correlation of angularity with SC-MY and MY-305 as 0.06 \pm 0.01 and $0.02 \pm 0.000$, respectively. Similar results have been reported by Khan and Khan (2016) showing correlations of the magnitude of $0.06 \pm 0.00$ and $0.5 \pm 0.00$, respectively. Very high genetic correlation of angularity with milk yield as 0.58 and $0.32 \pm 0.04$ has been shown by Bilal et al., (2016) and Zink et al., (2014), respectively differeing with the results of current study.

Rump angle: Negative phenotypic correlations with SCMY (-0.12 \pm 0.03$)$ while positive for MY-305 $(0.15 \pm 0.04)$ with rump angle were found in current study. Some workers have reported this correlation in the range of less than 0.10 (Erf et al., 1992; Short and Lawlor 1992; Cruickshank et al., 2002).

In our study, genetic correlation of rump angle with SC-MY and MY-305 was $0.15 \pm 0.03$ and $0.11 \pm 0.0001$, respectively. The findings of Bohlouli et al. (2015) as $0.13 \pm 0.19$ and Van Niekerk et al. (2000) as 0.10 are in agreement with our findings. Other reports have shown higher values of this correlation $(>0.50)$ (DeGroot et al., 2002; Jadoa, 2010). Low genetic correlation with milk yield suggest that rump angle is independent of milk producing genes and selection for one trait will not affect the other trait in Nili Ravi buffaloes.

Rump width: It was found that rump width was negatively correlated phenotypically with SC-MY ($0.16 \pm 0.05)$ and positively correlated with MY-305 (0.13 \pm 0.04$)$. Alimzhanova et al. (2018) has reported slightly lower value as 0.07 in Black and White Holstein cows and 0.13 in Simmental cows. The phenotypic correlation of rump width with milk yield $(-0.52 \pm 0.07)$ reported by Dahiya and Rathi (1997) in Sahiwal cows was highly negative. Most of the reports indicated a positive but very low $(<0.10)$ phenotypic correlation of rump width with milk yield.

Estimated genetic correlations of rump width with SC-MY and MY-305 were found as $0.30 \pm 0.05$ and $0.19 \pm 0.0002$, respectively. Haas et al. (2007) reported this correlation as $0.18 \pm 0.02$ in Red and White cows and Jadoa (2010) as 0.21 in Holstein cows, matching these results. Campos et al. (2015) reported relatively less value as $0.06 \pm 0.06$ in Red and White cows. Some 
contrasting reports showed negative genetic correlation of rump width with milk yield (Viji, 1990 in Tharparkar cows, Erf et al. 1992 in Holstein cows and Haas et al. 2007 in Brown Swiss cows). Considerable amount of genetic correlation with milk yield suggested that buffaloes with wider conformation at rump region tend to produce more milk and rump width is important in this breed of buffaloes and can be used as indirect selection criterion while selecting for improved milk yield.

Conclusions: A positive genetic correlation of stature with milk yield suggested that taller and heavier buffaloes produced more milk but the efficiency of milk yield must be well studied before making indirect selection for milk yield through stature. Negative phenotypic correlation of chest width with score day milk yield suggested that buffaloes with wider chest are relatively less efficient in milk production. Further studies are needed with larger sample sizes to verify the results. The findings of current study suggested that body depth would be useful indicator of indirect selection for higher milk yield in Nili Ravi buffaloes but angularity and rump angle are not important linear type functional traits for milk production. Substantial magnitude of genetic correlations of rump width with milk yield provided that rump width is important in Nili Ravi buffaloes and could be exploited as selection criterian for better milk production.

Acknowledgements: The authors are thankful to Prof. Dr. Khalid Javed for his help in analysis of data and critical review of manuscript. The cooperation and support of Incharges of 5 Govt. Livestock Experiments Stations in Punjab is highly acknowledged. This research project was funded by the Higher Education Commission of Pakistan under HEC-5000 Ph.D. scholarship program.

\section{REFERENCES}

Alimzhanova L. V., S. K. Bostanova, and Y. N. Sheiko (2018). The Level of Milk Production, Depending on the Exterior Traits of Dairy Cows. Online J. of Biological Sci. 18 (1): 29.36.

Bilal G., R. I. Cue, and J. F. Hayes. (2016). Genetic and phenotypic associations of type traits and body condition score with dry matter intake, milk yield, and number of breedings in first lactation Canadian Holstein cows. Canad. J. Anim. Sci. 96: 434-447.

Bohlouli M., A. Sadegh, and M.R. Varposhti (2015). Genetic relationships among linear type traits and milk production traits of Holstein dairy cattle. Ann. Anim. Sci., 15, No. 4: 903-917.

Campos R. V., A. C. Jaime, and E. L. Kern (2015). Genetic Parameters for Linear Type Traits and Milk, Fat, and Protein Production in Holstein Cows in Brazil. Asian Austral. J. Anim. Sci. 28(4): 476-484
Cruickshank J. K., A.Weigel, M.R. Dentine, and B.W. Kirkpatrick (2002). Indirect prediction of herd life in Guernsey dairy cattle. J. Dairy Sci. 85:1307-1313.

Dahiya S. P., and S.S. Rathi (1997). Scanning of linear functional type traits for milk production in Sahiwal cattle. Indian J. Anim. Sci. 67(9): 792797.

DeGroot B.J., J.F. Keown, L.D. van-Vleck, and E.L. Marotz (2002). Genetic parameters and responses of linear type, yield traits, and somatic cell scores to divergent selection for predicted transmitting ability for type in Holsteins. J. Dairy Sci. 85(6): 1578-1585.

Devan C.F., B.L. Hansen, and A.F. Denis (1991). Adjustment of linear type scores from Holstein classification for age and stage of lactation. J. Dairy Sci. 74: 645-650.

Erf D. F. L., B. Hansen, and D.A. Lawstuen (1992). Inheritance and relationships of workability traits and yield for Holsteins. J. Dairy Sci. 75:1999-2007.

Gilmour A. R., B.J. Gujel, B.R. Cullis, and R. Thompson (2009). ASREML User Guide (Version 3.0), VSN International Ltd, Hemel Hempstead, HP1 1ES, UK.

Haas Y.de, L.L.G. Janss, and H.N. Kadarmideen (2007). Genetic and phenotypic parameters for conformation and yield traits in three Swiss dairy cattle breeds. J. Anim. Breed. \& Genet. 124 (1): 12-19.

ICAR. (2007). International Agreement of Recording Practices, Approved on 9 June, 2006.

Jadoa A. J. (2010). Type traits and milk yield genetic parameters and breeding values of Holstein in Iraq. Basra J. Vet. Res. 9(1): 40-52.

Khan M. A., and M.S. Khan (2016). Genetic and phenotypic correlations between linear type traits and milk yield in Sahiwal cows. Pakistan J. Agri. Sci., 53(2), 483-489.

Mirza R. H., K. Javed, M. Abdullah and T. N. Pasha (2013). Genetic and non genetic factors affecting body condition score in Nili Ravi buffaloes and its correlation with milk yield. The J. Anim. and Plant Sci. 23(6): 1486-1490.

Norman H. D., R.L. Powell, J.R. Wright, and B.G. Cassell (1988). Phenotypic and genetic relationship between linear functional type traits and milk yield for five breeds. J. Dairy Sci. 71(7): 1880-1896.

Parke P.Jr., B.W. Kennedy, J.C.M. Dekkers, R.K. Moore, and L. Jairath (1999). Genetic and phenotypic parameter estimates between production, feed intake, feed efficiency, body weight and linear type traits in first lactation Holsteins. J. Dairy Sci. 79: 425-431. 
Patterson H.D., and R. Thompson (1971). Recovery of inter-block information when block size are unequal. Biometrika. 58(3): 545-554.

SAS Instt. Inc. (2011). SAS/STAT user's guide, Release 9.1.Carry, North Carolina, USA

Short T.H., and T.J. Lawlor (1992). Genetic parameters of conformation traits, milk yield, and herd life in Holsteins. J. Dairy Sci. 75:1987-1998.

Tapki I. and Y. Z. Guzey (2013). Genetic and Phenotypic Correlations between Linear Type Traits and Milk Production Yields of Turkish Holstein Dairy Cows. Greener J. of Agri. Sci. 3 (11):755761.

Van Niekerk D.J., F.W.C. Neser, and G.J. Erasmus ( 2000). Genetic parameter estimates for type traits in the South African Jersey breed. South Afric. J. Anim. Sci. 30(3): 186-192.

Viji P.K., D.S. Balain, M.George, and A.K. Vinayak (1990). Linear type traits and their influence on milk production in Tharparkar cattle. Ind. J. Anim. Sci. 60(7): 845-852.
Xiaoping Wu., F. Ming, L. Lin, W. Sheng, L. Jianfeng, D. Xiangdong, Z. Shengli, Z. Qin Zhang, Z. Yuan, Q. Lv, S.L Mogens, S. Guosheng and S. Dongxiao (2013). Genome wide association studies for body conformation traits in the Chinese Holstein cattle population. BMC Genomics, 14:897

Xiang R, L. M. MacLeod, S. Bolormaa, and M.E. Goddard. (2017). Genome-wide comparative analyses of correlated and uncorrelated phenotypes identify major pleiotropic variants in dairy cattle. Scientific Reports 7: 9248. DOI:10.1038/s41598-017-09788-9

Yanar M. (1999). Factors affecting linear type traits for Holstein Friesian cattle reared in Eastern Turkey. Indian J. Anim. Sci. 69(4) : 260-262.

Zink V. L. Zavadilova, J. Lassen, M. Stipkova, M. Vacek, and L. Stolc (2014). Analyses of genetic relationships between linear type traits, fat-toprotein ratio, milk production traits, and somatic cell count in first-parity Czech Holstein cows. Czech J. Anim. Sci., 59 (12): 539-547. 